\title{
Predikční model jakosti vody v okolí Prahy
}

\section{ADAM VIZINA, IRINA GEORGIEOVÁ, EVA JURANOVÁ, JAN HLOM}

Klíčová slova: jakost - hydrologie - průtoky - kvalita - predikce - Praha

\section{SOUHRN}

$\checkmark$ poslední době se velmi diskutuje - a to nejen mezi odbornou veřejností o dopadech změny klimatu na vodní režim v př́rodní krajině. Řešení OP Praha pól růstu se zaměřilo i na krajinu kulturní v bezprostřední blízkosti města Prahy, kde probíhal monitoring klimatologických veličin, průtoků a kvality vody na osmi pilotních lokalitách (povodích), jenž započal v dubnu 2018 a končil v květnu 2020. Analýza chemického složení vody pražských potoků byla prováděna Zkušební laboratoří technologií a složek životního prostředí VúV TGM, v. v. i. Ovlivnění dlouhodobého odtokového režimu bylo simulováno prostřednictvím modelu BILAN, který je na VúV TGM, v. v. i., dlouhodobě vyvíjen.

Vybrané ukazatele byly vyhodnoceny a staly se podkladem pro simulační model jakosti vody v závislosti na srážkoodtokových charakteristikách se zohledněním sezonnosti. Koncentrace byly odvozeny na základě regresních vztahů mezi aktuálním průtokem a koncentrací zvolené kvalitativní veličiny. Vznikl tak simulační model, jenž je volně k dispozici v mapové aplikaci na stránkách projektu heis.vuv.cz/projekty/praha-adaptacniopatreni. Výsledky monitoringu jsou pak dostupné v rámci interaktivní prohlížečky nebo na geoportálu vzniklém v rámci řešení (popis je v článku Strouhal a kol. tohoto čísla).

\section{ÚVOD}

Změna klimatu a stav krajiny mají významný vliv na vodní režim nejen v České republice, ale všude na Zemi. Poslední roky ukázaly, jak velká je setrvačnost celého prírodního systému a koloběhu vody a jaké dopady mohou mít změny nejen na vodní hospodářství. Na posun počátku vegetačního období, výrazné zvýšení teplot a nerovnoměrnou distribuci srážkových úhrnů upozorňuje odborná veřejnost již více než 20 let. Je velmi pravděpodobné, že výskyt extrémních hydrologických jevů (hydrologické sucho - nedostatek vody, povodně) s sebou přinesou také změny kvalitativní. Pro odhad těchto změn byl vyvinut jednoduchý robustní model, navazující na model hydrologické bilance BILAN, který je nenáročný na vstupní data (srážkové úhrny a teploty vzduchu). Výhodou tohoto modelu je nejen predikce aktuálních odtoků a koncentrací na osm týdnů dopředu, ale také možnost simulace dopadů klimatické změny dle jednotlivých výstupů z globálních/regionálních cirkulačních modelů.

\section{POZOROVANÁ DATA A ZÁJMOVÉ ÚZEMÍ}

Sledování chemického složení povrchové vody pražských potoků prováděla Zkušební laboratoř technologií a složek životního prostředí VúV TGM, v. v. i. Monitoring byl započat v dubnu 2018 a ukončen v květnu 2020, trval tedy více než dva roky. Odběry byly realizovány na devíti vybraných profilech, jež jsou zobrazeny na obr. 1 (oranžové polygony se závěrným profilem) a nacházejí se v územním prstenci zahrnujícím území okrajových částí Prahy podél hranic hlavního města se Středočeským krajem. Prstenec byl vytvořen s využitím hranic povodí 4. řádu (prípadně jejich částí), je tedy dobře hydrologicky definován z hlediska odtokových poměrů. Hranice zájmového území jsou stanoveny tak, aby neobsahovaly historická zastavěná území vnitřní Prahy, ale naopak zahrnovaly území vnější Prahy, kde v posledních desítkách let dochází k největším změnám ve využití krajiny a s tím souvisejícím změnám odtokových poměrů. Na základě analýzy bylo vybráno celkem šest pilotních povodí tak, aby výsledky zjištěných změn odtokových poměrů vlivem změn využití území byly dobře generalizovatelné na celé zájmové území prstence. Jedná se o:

A. Kopaninský potok - povodí reprezentuje vodní poměry na severozápadě Prahy ovlivněné denudačními zbytky kř́idových sedimentů (vyšší základní odtok), povodí je poznamenáno existencí letiště.

B. Motolský potok - povodí reprezentuje poměry západní části Prahy ovlivněné denudačními zbytky křídových sedimentů, povodí je silně antropogenně pozměněno v posledních 100 letech mohutnou výstavbou.

C. Dalejský potok - povodí je charakterizováno významnými zájmy ochrany prírody (Prokopské údolí, geologický charakter utvářen svrchnopaleozoickými vápenci), v horních částech povodí ale od 60. let probíhala masivní výstavba.

D. Lipanský potok - reprezentuje odtokové poměry soutokového území VItavy a Berounky v jižní části Prahy. Geologicky jde o prostředí kvartérních fluviálních štěrkopískových náplavů. Jde o území s relativně malými dopady zástavby na využití krajiny.

E. Drahanský potok - povodí bylo vybráno s ohledem na doposud zachovaný převažující volný a prírodní charakter území (pole, lesy, louky) a relativně malou zastavěnost.

F. Vinořský potok - ukazuje odtokové poměry ve východní části Prahy, specifikem je jeho odtok z Prahy do Středočeského kraje (př́tok Labe). Povodí je poznamenáno významnou zástavbou v různých historických obdobích (letiště Kbely), včetně mohutného dnešního rozvoje (katastry Kbel, Satalic, Vinoře), zajímavostí je zde i golfové hřiště.

Bodové vzorky $v$ pilotních lokalitách byly odebírány dvakrát měsíčně. $\checkmark$ některých profilech nebylo možné realizovat monitoring $v$ plném rozsahu z technických důvodů - stavebních úprav koryta toku nebo nedostatku vody v období sucha (např. profil Lipanský potok).

Při odběru vzorků byly v terénu stanoveny základní fyzikálně-chemické ukazatele: teplota vody (T), teplota vzduchu (Tvz), pH, elektrická konduktivita (K) (viz obr. 2). V laboratoři pak byly $\vee$ odebraných vzorcích stanovovány tyto ukazatele: 
hydrogenuhličitany (HCO3-), kyselinová neutralizační kapacita (KNK4,5), biochemická spotřeba kyslíku (BSK5), chemická spotřeba kyslíku dichromanem (CHSKCr), chloridy (Cl-), sírany (SO42-), amonné ionty (NH4+), amoniakální dusík (N-NH4+), dusičnany (NO3-), dusičnanový dusík (N-NO3-), nerozpuštěné látky (NL), celkový fosfor (Pcelk.), sodík (Na), draslík (K), vápník (Ca), hořčík (Mg), železo (Fe) a mangan (Mn). Všechny postupy použité pro analýzy i odběry povrchové vody vycházejí z platných norem a jsou akreditovány u Českého institutu pro akreditaci a posouzeny střediskem posuzování laboratoří ASLAB.
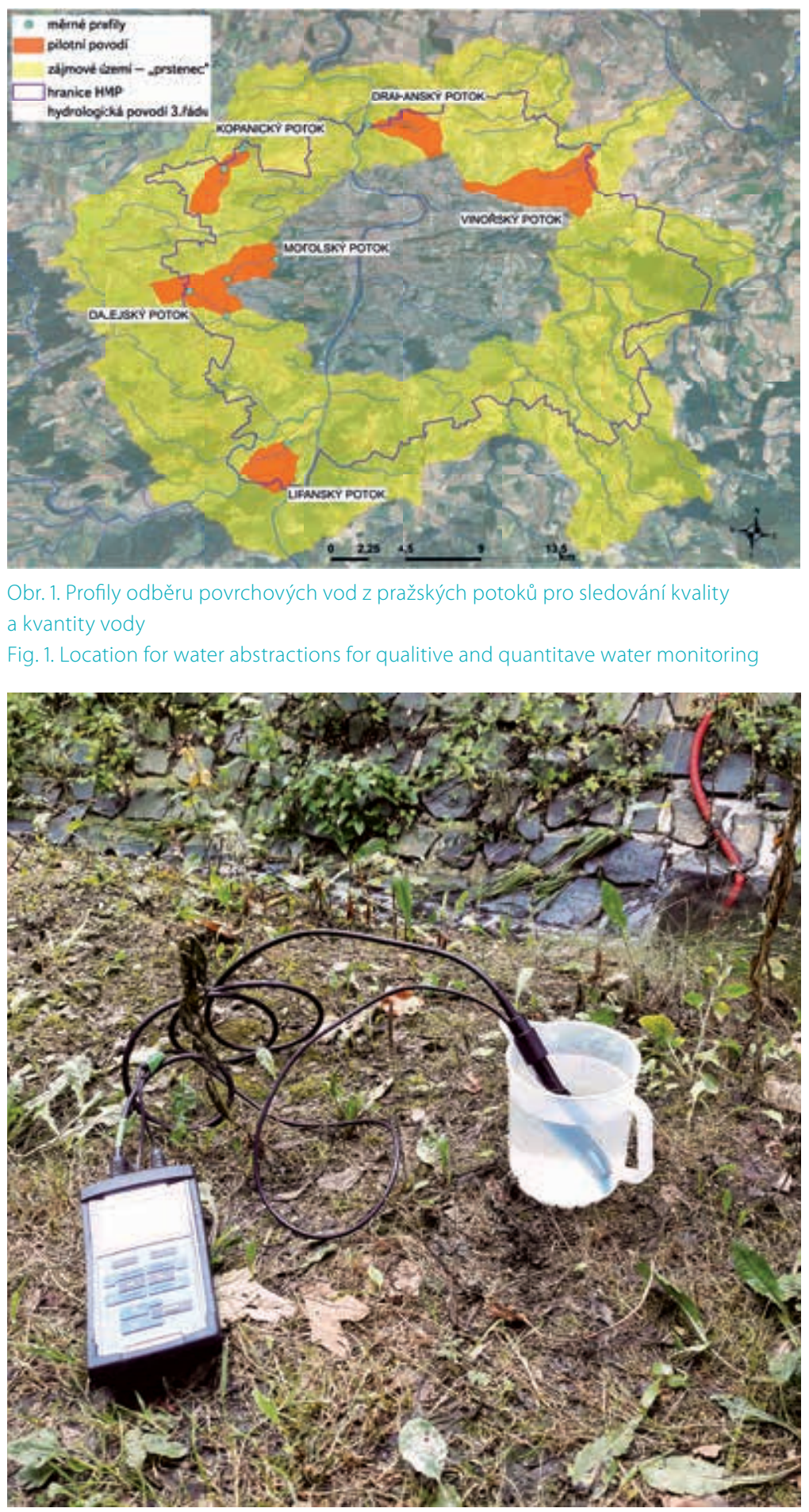

Obr. 2. Terénní měření elektrické konduktivity a pH

Fig. 2. On site monitoing of electrical conductivity and pH
Na pilotních lokalitách byly vybudovány měrné stanice pro měření průtoků (obr. 1). Zároveň byla postavena srážkoměrná stanice v povodí Lipanského potoka. Většina stanic je osazena dálkovým přenosem, který každý den odesílá pomocí GSM signálu naměřená data (výšku hladiny, teploty, príipadně srážkové úhrny).

Ukázka pozorování průtoků je na obr. 3. Jde o dolní profil Motolského potoka pod Motolskými rybníky. Průtok je měřen neprímo pomocí pozorování hladiny tlakoměrnou sondou před měrnými půlkruhovými přelivy umístěnými v korytě toku. Vlastní prèlivy jsou ukotveny $v$ polyetylenové desce umístěné do koryta prostřednictvím úhelníků a vrutů. Těsnění přelivu je zajištěno pomocí geotextilie na přelivu i před ním. Motolský potok následně pokračuje jeden kilometr po povrchu a poté je zatrubněný pod povrchem až do jeho ústí do Vltavy.

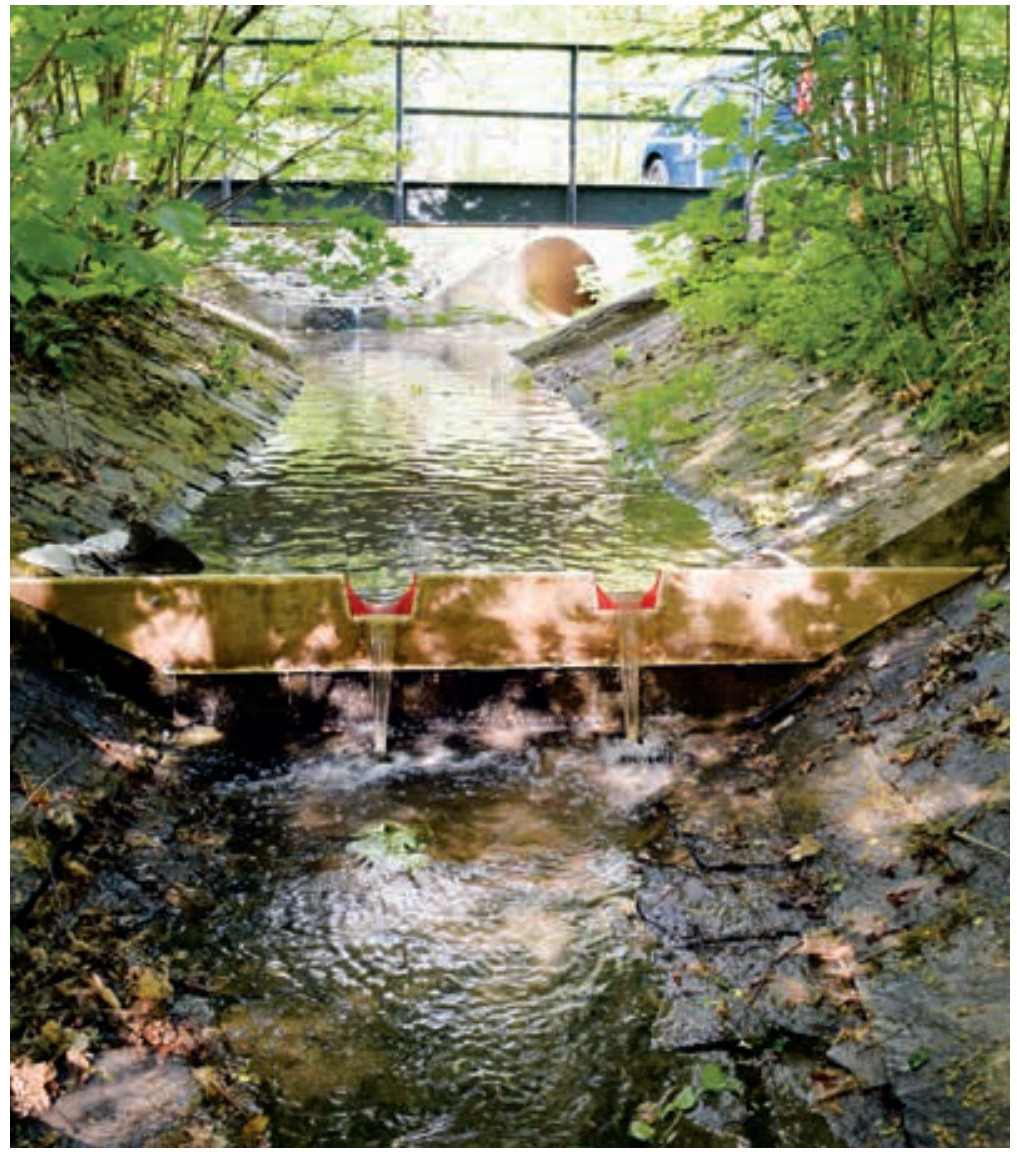

\section{SIMULAČNÍ MODEL}

Simulační model je založen na propojení modelu hydrologické bilance Bilan a koncentračního modelu pro jednotlivé látky a pozorované profily a lokality. Jeho cílem je podat obraz o vývoji koncentrací látek uvedených v tab. 1 v Praze a okolí na základě modelování průtoků modelem Bilan s následným odvozením koncentrací pro jednotlivé látky. Postup prací je následující:

kalibrace modelu hydrologické bilance Bilan (nebyl v rámci projektu vyvijen) na pozorovaných časových řadách (odtok, teplota vzduchu a srážkové úhrny), získání kalibračních parametrů modelu pro jednotlivá povodí 
2. odvození regresních vztahů mezi koncentrací dílčích látek a průtokem

3. implementace těchto vztahů do koncentračního modelu

4. tvorba webového rozhraní

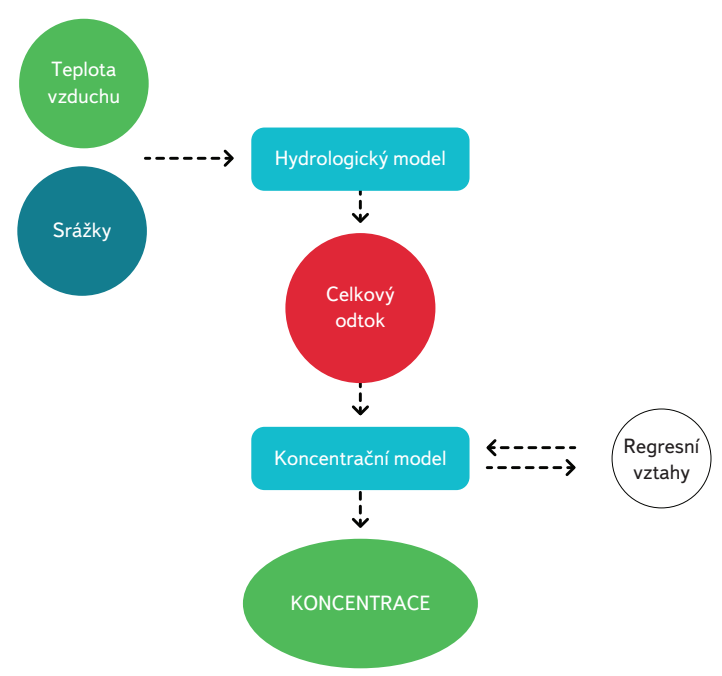

Obr. 4. Schéma simulačního modelu

Fig. 4. Scheme of simulating model

Pro zvolené profily jsou odvozena hydrologická povodí, pro něž jsou modelovány veličiny hydrologické bilance a následně jsou v těchto profilech odvozeny průtoky na základě dostupných klimatických dat.

Tab. 1. Přehled pozorovaných a hodnocených látek

Tab. 1. Overview of observed and evaluated substances

\begin{tabular}{llll} 
Veličina & Jednotka & Veličina & Jednotka \\
\hline Elektrická konduktivita & $\mathrm{S} / \mathrm{cm}$ & & \\
\hline Hydrogenuhličitany & $\mathrm{mg} / \mathrm{l}$ & Nerozpuštěné látky & $\mathrm{mg} / \mathrm{l}$ \\
\hline KNK 4.5 & $\mathrm{mmol} / \mathrm{l}$ & Teplota (vody) & ${ }^{\circ} \mathrm{C}$ \\
\hline $\begin{array}{l}\text { Biochemická } \\
\text { spotřeba kyslíku }\end{array}$ & $\mathrm{mg} / \mathrm{l}$ & Teplota (vzduchu) & ${ }^{\circ} \mathrm{C}$ \\
\hline $\begin{array}{l}\text { Chemická } \\
\text { spotřeba kyslíku } \\
\text { dichromanem }\end{array}$ & $\mathrm{mg} / \mathrm{l}$ & Celkový fosfor & $\mathrm{mg} / \mathrm{l}$ \\
\hline $\begin{array}{l}\text { Chloridy } \\
\text { Sírany }\end{array}$ & $\mathrm{mg} / \mathrm{l}$ & Sodík & $\mathrm{mg} / \mathrm{l}$ \\
\hline Amonné ionty & $\mathrm{mg} / \mathrm{l}$ & Draslík & $\mathrm{mg} / \mathrm{l}$ \\
\hline $\begin{array}{l}\text { Dusičnany } \\
\text { Amoniakální dusík }\end{array}$ & $\mathrm{mg} / \mathrm{l}$ & Vápník & $\mathrm{mg} / \mathrm{l}$ \\
\hline $\begin{array}{l}\text { Dusičnanový dusík } \\
\mathrm{mg} / \mathrm{l}\end{array}$ & Mangan & $\mathrm{mg} / \mathrm{l}$ \\
\hline
\end{tabular}

\section{MODEL BILAN}

Model Bilan [1], [2] simuluje pro dané povodí složky hydrologické bilance. Struktura modelu je dána vztahy, které popisují základní principy hydrologické bilance na povrchu, v půdní zóně, jež je ovlivněna vegetačním pokryvem, a v zóně podzemní vody. Pro stanovení energetické bilance, která má na složky hydrologické bilance významný vliv, slouží teplota vzduchu. Časové rozlišení modelu pro varovný simulační systém je jeden týden.

Vstupními daty pro výpočet hydrologické bilance jsou řady srážek na povodí a teploty vzduchu. Ke kalibraci parametrů modelu jsou pozorovány řady odtoku a dlouhodobé charakteristiky odtoku, jako je průměrný průtok a dolní průtokové kvantily. Model simuluje časové řady týdenní potenciální evapotranspirace, územního výparu, infiltrace do půdy a dotace podzemní vody z půdy do podzemních vod. Všechny tyto hydrologické veličiny se vztahují k celému povodí. Celkový odtok se skládá ze tří součástí, jimiž jsou prímý, hypodermický a základní odtok. Model má osm volných parametrů a k jejich kalibraci na pozorovaných povodích použivá optimalizační algoritmus. Schéma modelu Bilan je znázorněno na obr. 5 a podrobnější informace lze nalézt na webu https://bilan. vuv.cz.

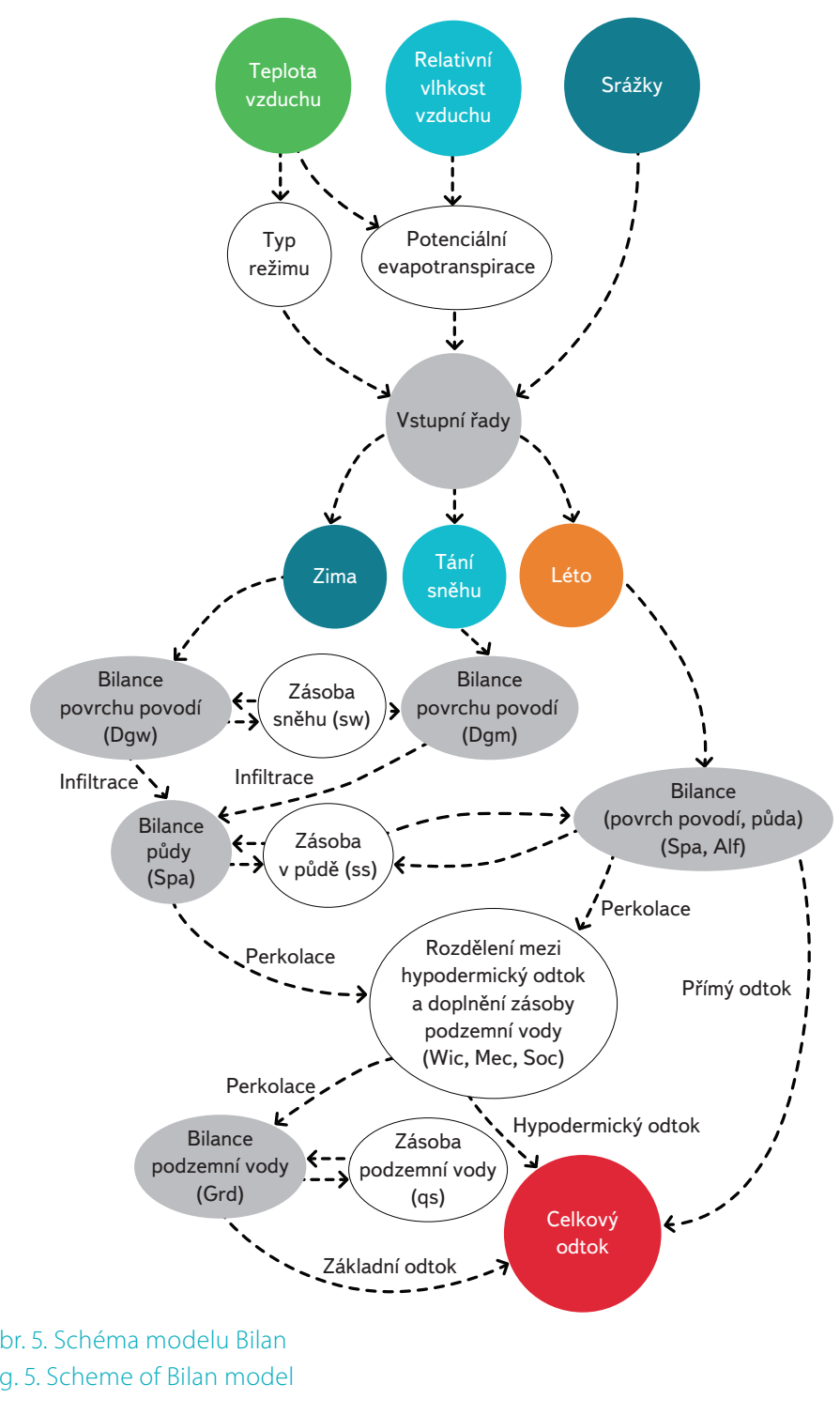




\section{KONCENTRAČNÍ MODEL}

Koncentrační model je založen na základní směšovací rovnici:

$$
c=\frac{m}{V}=\frac{m}{Q}
$$

$$
\begin{array}{cl}
\text { kde } \quad c \text { je } & \text { koncentrace, } \\
\text { m } & \text { hmotnost, } \\
\text { V objem, } \\
\text { Q } & \text { průtok. }
\end{array}
$$

Pomocí závislosti koncentrace c a průtoku Q v každém hodnotícím profilu jsou odvozeny vztahy pro jednotlivé látky pomocí regresních modelů I. až III. rádu. Odvozené vztahy pro jednotlivé profily a látky byly doplněny do koncentračního modelu. Na základě těchto vztahů je možné simulovat koncentrace látek, jež byly v projektu analyzovány. Pro lepší reprezentativnost by byl vhodný delší monitoring na všech lokalitách, tak aby byly k dispozici i epizodní situace, např́klad období zvýšených průtoků. Cílem bylo vytvoření nástroje, který dokáže na základě predpovědi počasí upozornit na prípadný problém $\checkmark$ daném povodí.

\section{PREDIKCE A WEBOVÁ PROHLÍŽEČKA}

Pomocí odvozených parametrů hydrologického modelu Bilan je možné simulovat průtoky v týdenním kroku po zadání teplot vzduchu a srážkových úhrnů na osm týdnů dopredu. Hodnoty klimatických veličin mohou být zadány pro vybrané povodí (profil):

- ručně: vyplní se na základě odborného odhadu nebo aktuálních predikcí,

- automaticky: do modelu jsou automaticky doplněny průměrné hodnoty

pro jednotlivé týdny ve výhledu osmi týdnů pro zvolené období.

Po simulaci průtoků modelem Bilan jsou odvozeny predikované koncentrace jednotlivých látek na základě zjištěných regresních vztahů (koncentrační model). Následně je vyhodnoceno, zda koncentrace přesahují mez detekovatelnosti, či na tuto hranici nedosahují.

Výsledky samotného varovného systému jsou prezentovány pomocí webové aplikace. Ta je tvořena $\vee$ programovacím jazyce $R$ prostřednictvím balíčku umožňujícího tvorbu interaktivních webových aplikací Shiny. Kód je koncipován jako R Markdown dokument s výstupním formátem flexdashboard, což je balíček sloužící k integraci aplikace do jednotného zobrazení (tzv. dashboardu). Interaktivní prvky aplikace jsou tvořeny baličky, zprostředkovávajícími integraci open source JavaScript knihoven do R. Konkrétně se jedná o leaflet pro tvorbu map, dygraphs pro tvorbu grafü časových řad a rhandsontable pro interaktivní tabulkové výstupy. Pro manipulaci s daty na pozadí aplikace je použit balíček dplyr a pro práci s datumy balíček lubridate, oba jsou součástí prostředí tidyverse - souboru open source balíčků, navržených se společným API, filozofií, základní gramatikou a strukturou dat. K modelováni odtoku byl využit model hydrologické bilance reprezentovaný balíčkem bilan. K odhadu samotného modelu a tvorbě predikcí byly použity nástroje ze základního balíčku stats. Nízký počet balíčků, a tedy dependencies aplikace, umožňuje její snadnější udržitelnost a provoz. V aktuálním stavu je aplikace určena pro R verze 3.6.1 (2019-07-05). Verze jednotlivých baličků jsou uvedeny v tab. 2.
Tab. 2. Seznam R balícků použitých v aplikaci

Tab. 2. List of used R-packages

\begin{tabular}{lll} 
Název & Verze & Popis \\
\hline shiny & 1.5 .0 & Web Application Framework for R \\
\hline flexdashboard & 0.5 .2 & R Markdown Format for Flexible Dashboards \\
\hline leaflet & 2.0 .3 & $\begin{array}{l}\text { Create Interactive Web Maps with the } \\
\text { JavaScript 'Leaflet' Library }\end{array}$ \\
\hline dygraphs & 1.11 .6 & $\begin{array}{l}\text { Interface to 'Dygraphs' Interactive Time } \\
\text { Series Charting Library }\end{array}$ \\
\hline rhandsontable & 0.3 .7 & Interface to the 'Handsontable.js' Library \\
\hline dplyr & 1.0 .2 & A Grammar of Data Manipulation \\
\hline lubridate & 1.7 .9 & Make Dealing with Dates a Little Easier \\
\hline bilan & $2018-11-29$ & Bilan water balance model
\end{tabular}

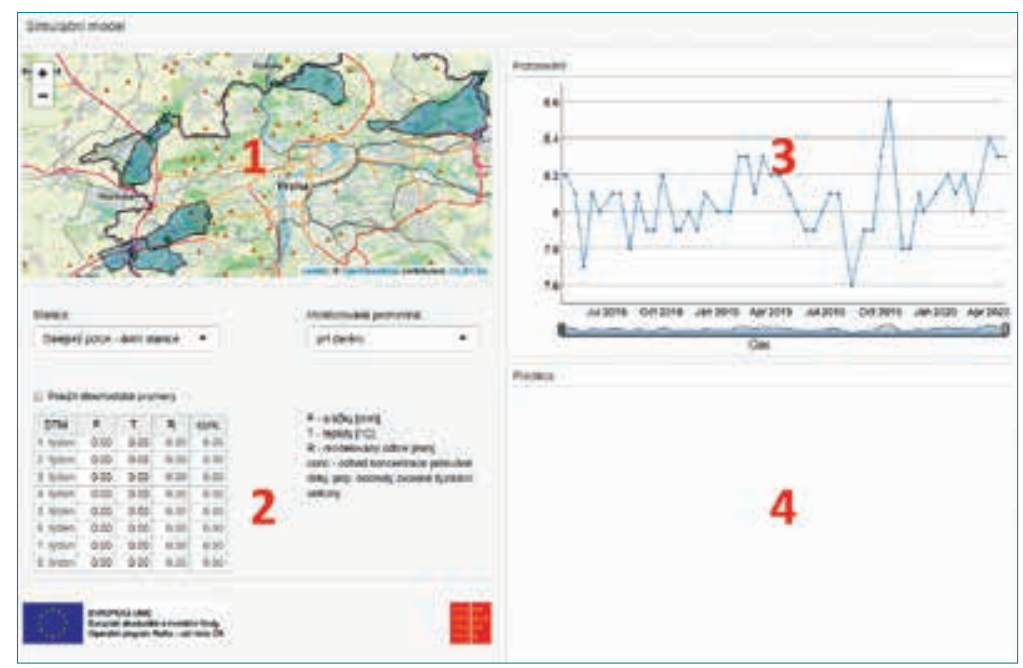

Obr. 6. Základní rozdělení aplikace (v okně 3 jsou zobrazeny pozorované hodnoty pH) Fig. 6. Aplication window (window 3 showing values of $\mathrm{pH}$ )

Na obr. 6 je zobrazeno základní okno aplikace, jež je rozděleno do čtyř částí:

1. Mapové okno, zobrazující lokalizaci jednotlivých profilů/povodí, které je interaktivní. Po kliknutí na daný profil/povodí se v ostatních oknech aplikace zobrazí výsledky pro zvolený profil/povodí.

2. Okno zobrazující pozorované hodnoty koncentrací pro zvolenou látku a profil/povodí.

3. Okno, jež umožňuje výběr látky, profilu/povodí a zadání výhledových hodnot teplot vzduchu a srážkových úhrnů nebo volbu datumu, pro které má být provedena predikce. Zobrazovací komponenta je interaktivní a po přiblížení myší zobrazí hodnoty.

4. Okno zobrazující predikované hodnoty koncentrací pro zvolenou látku a profil/povodí. 
Samotné zobrazení výsledů v aplikaci je prípustné i bez přihlášení se do ní. $\checkmark$ rámci aplikace je $k$ dispozici manuál, jenž obsahuje metodický popis a informace o jednotlivých modelovaných lokalitách a povodích.

Pomocí rolovacího menu Ize pro dílčí oblast vybrat jednotlivý profil/povodí. Tuto volbu lze také provést v mapovém okně, které disponuje standardní funkcionalitou. Po zvolení profilu/povodí a vybrané látky se v pravém horním rohu zobrazí pozorované hodnoty koncentrací. Limitní hodnoty (mez detekovatelnosti) jsou v okně zobrazeny pomocí číselného údaje.

$\checkmark$ rámci aplikace Ize provádět predikce koncentrací zvolené látky na osm týdnů dopředu. Je možné použít dlouhodobé průměry teplot vzduchu a srážkových úhrnů. $V$ takovém prípadě se vyplní tabulka dlouhodobými průměry za období 1981-2010 teplot vzduchu (T) a srážkových úhrnů (P). Poté se automaticky vypočtou průtoky/odtoky (R) a následně koncentrace pro danou látku. Hodnoty koncentrací se objeví v tabulce v číselné formě ve sloupci cons. Hodnoty 1-8 označují 1. až 8. týden od zvoleného data. Průběh predikovaných hodnot se dále zobrazí v grafu Predikce a profily/povodí se obarví červenou, či modrou barvou. Červená značí, že se hodnoty pohybují nad hranicí detekovatelnosti, modrá, že jsou pod touto limitní hodnotou. Další možností je zadat teploty vzduchu a srážkových úhrnů do tabulky ručně, např. na základě hydrometeorologické předpovědi.

\section{VÝSLEDKY A DISKUZE}

Na plochu povodí byla na základě reálně měřených dat vypočitána modelová data za období 1961-2017 v denním kroku pro srážky a teploty. Obr. 7 ukazuje základní statistické porovnání tří po sobě následujících období v agregovaných měsíčních hodnotách, z nichž je patrný postup klimatických změn, a to především u teplot vzduchu. Klimatologické veličiny byly na povodí vyhodnoceny pro tři časová období (1961-1990, 1991-2005 a 2006-2017) a jsou znázorněny
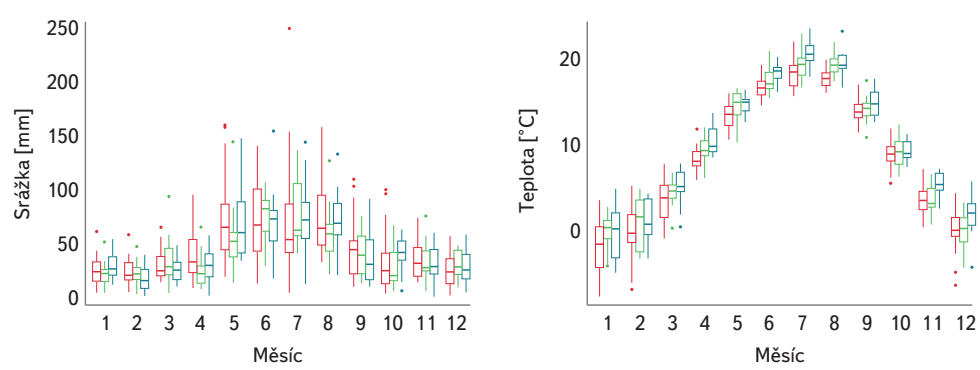

Obdob

\section{$1961-1990$}

Obr. 7. Motolský potok - srážky a teploty vzduchu

Fig. 7. Motols creek - precipitation and air temperature

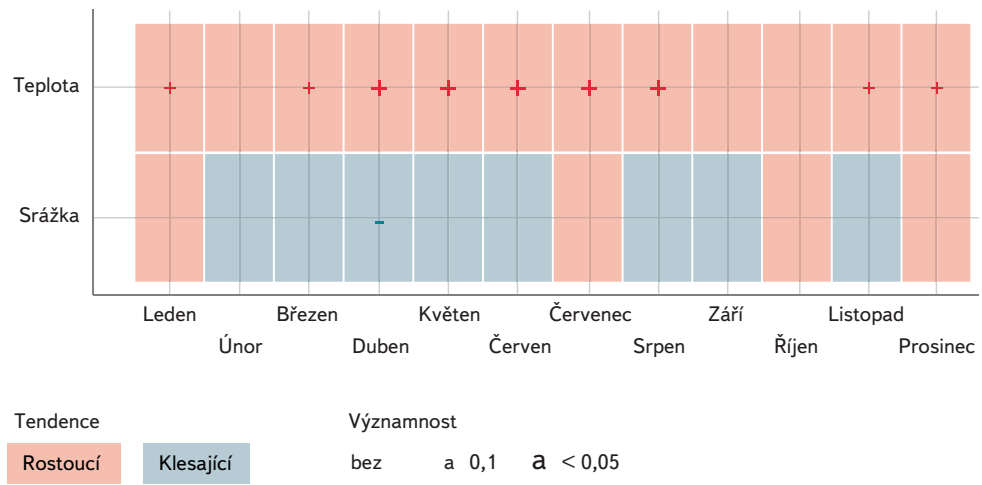

Obr. 8. Motolský potok - hodnocení významnosti trendů změn srážek a teplot v jednotlivých měsících

Fig. 8. Motols creek - evaluation of the significance of trends in changes in precipitation and temperature

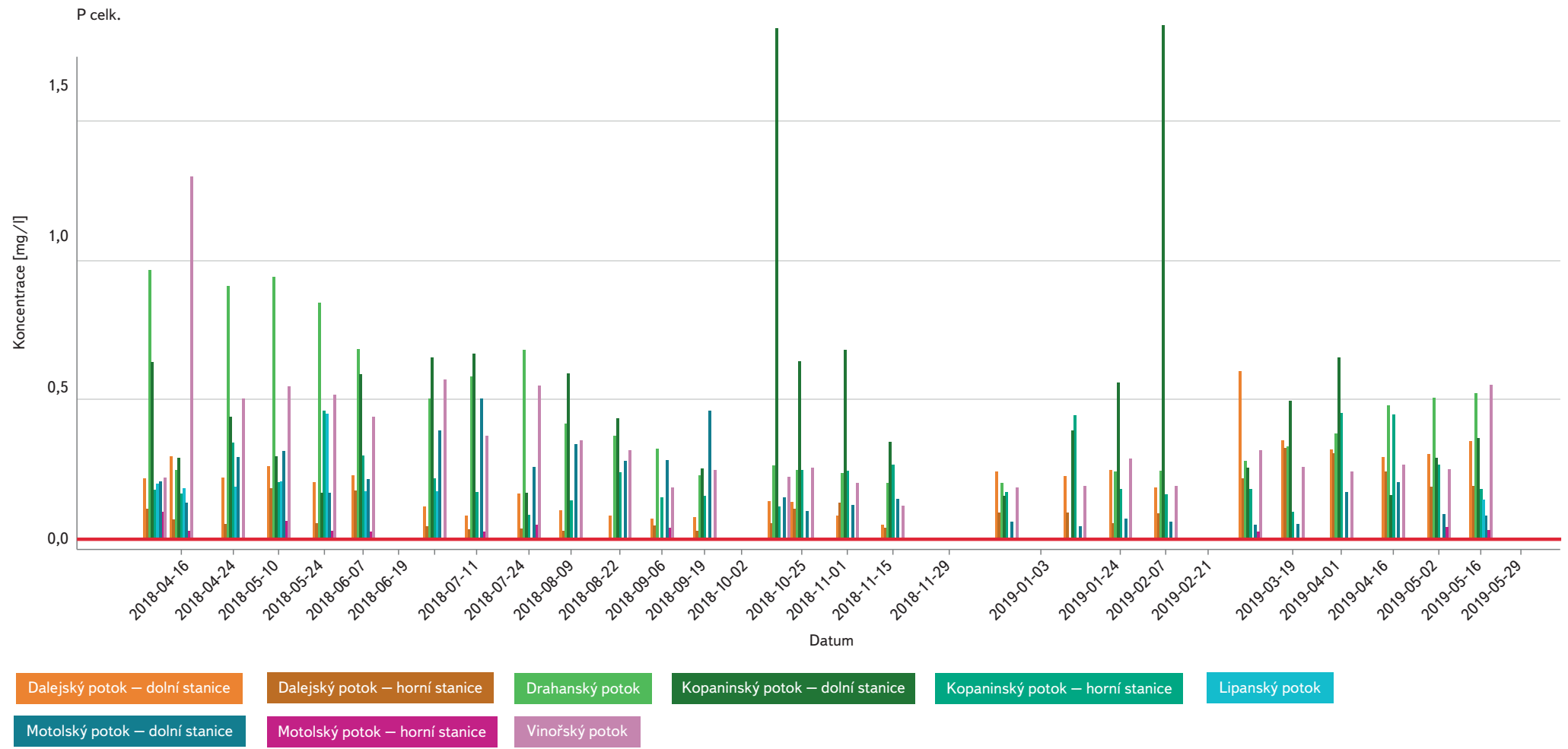

Obr. 9. Koncentrace fosforu pro jednotlivá povodí

Fig. 9. Phosphorus concentrations for individual river basins 
formou boxplotů na obr.7a 8. Jednotlivá období jsou od sebe barevně odlišena. Na obr. 7 Ize vidět, že z pohledu průměrných měsíčních úhrnů bylo prostřední hodnocené období 1991-2005 srážkově spíše nadprůměrné a současný stav se přiblížil zpět podmínkám v prvním období 1961-1990.

Statistická signifikantnost trendu měsičních srážkových úhrnů a teplot vzduchu za celé období 1961-2019 byla posouzena Mann-Kendalovým testem. Výsledky jsou zobrazeny na obr. 8. Lze pozorovat statisticky významný nárůst teploty s vysokou hladinou významnosti predevším v měsících na počátku vegetačního období, kdy naopak srážkové úhrny mají spíše klesající, ač statisticky málo významnou tendenci.

Na obr. 9 jsou jako príklad zobrazeny pozorované koncentrace fosforu pro jednotlivá povodí. Lze pozorovat významný rozdíl mezi jednotlivými povodími.

Na obr. 10 je znázorněna predikce pro osm týdnů, pokud by následovaly průměrné hydroklimatické podmínky. Zobrazen je profil/povodí Kopaninský potok - dolní stanice (zvýrazněn i v mapovém podkladu) a látka Diclofenac $\checkmark$ rámci predikce lze pozorovat, že se koncentrace na počátku pohybují těsně nad mezí detekovatelnosti, následně pod tuto hranici klesnou a na konci období se opět nad tuto hranici dostanou. Hodnoty se pro zvolený profil/ povodí pohybují nad zvolenou mezí, v mapové komponentě je však zřejmé, že v jiných povodích tomu tak nemusí být.

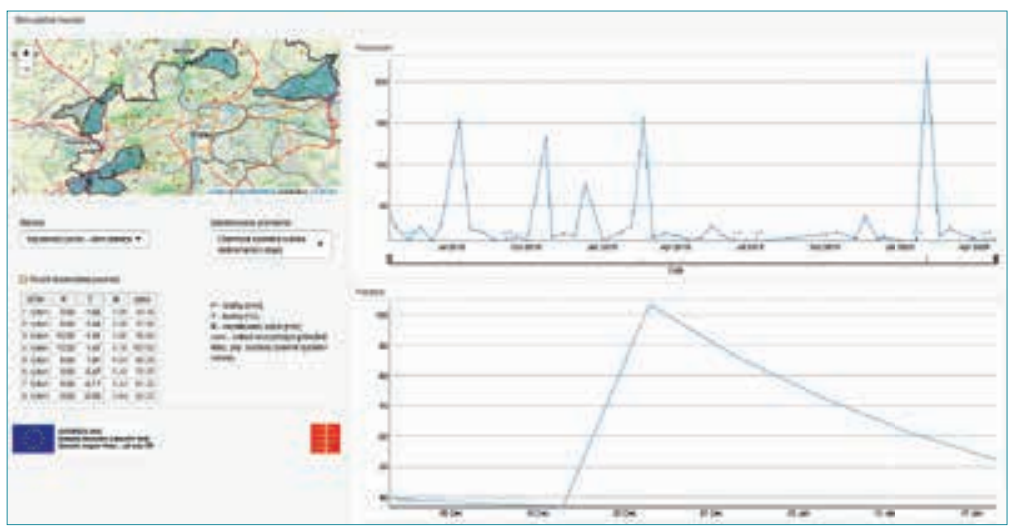

Obr. 10. Výsledky predikce pro zvolenou látku (chemická spotřeba kyslíku dichromanem $\checkmark \mathrm{mg} / \mathrm{l})$ a povodí Kopaninského potoka

Fig. 10. Prediction results for the selected substance (chemical oxygen demand with dichromate $\mathrm{mg} / \mathrm{l}$ ) and the Kopaninský stream basin

Pro podrobnější prezentaci pozorovaných (monitorovaných) hodnot koncentrací látek, průtoků, teploty vody a konduktivity byla vzhledem k velkému množství dat vytvořena interaktivní prohlížečka $v$ prostředí $R$ Shiny. Funkcionalita prohlížečky je založena na aplikaci simulační model, která vznikla $\checkmark$ rámci řešení projektu. Po přihlášení do prohližečky lze zvolit, zda chceme zobrazit výsledky pro oblast.

Následně je možné vybrat jednu z látek, jež byly vyhodnoceny. V samotné prohlížečce je možné vybrat najednou až 10 látek (průtoky, teplota vody, konduktivita) tak, aby je bylo možné mezi sebou porovnávat či např́klad vizuálně hodnotit závislost koncentrace na průtoku. Grafické výstupy jde exportovat ve formátu *.png.

\section{ZÁVĚR}

Pro oblast okolí Prahy byl vytvořen simulační model, jenž predikuje odtokové výšky (průtoky) a koncentrace vybraných látek na osm týdnů dopředu na základě (i) ručně zadaných hodnot teplot vzduchu a srážkových úhrnů nebo (ii) pomocí dlouhodobých průměrů klimatických veličin. Koncentrace jsou modelovány na základě kombinace předpovědi průtoků pomocí hydrologického modelu Bilan a koncentračního modelu. Pro jednotlivé látky a průtoky byly odvozeny regresní vztahy I. až III. rádu. Na základě těchto vztahů jsou poté dané koncentrace odhadnuty. Pro lepší vystižení závislosti by bylo vhodné v daných lokalitách látky dále monitorovat a následně tyto regresní vztahy upravit tak, aby byly zachyceny různé hydrologické situace a k nim odpovídající koncentrace jednotlivých látek. Do budoucna by bylo vhodné model upravit pro výpočet v denním časovém kroku. Model je uveden na stránkách projektu heis.vuv. cz/projekty/praha-adaptacniopatreni.

\section{Poděkování}

Tento článek byl připraven v rámci projektu „Analýza adaptačních opatření ke zmirnění dopadů změny klimatu a urbanizace na vodni režim v oblasti vnější Prahy", č. CZ.071.02/0.0/0.0/16-040/0000380, financovaného z Operačního programu Praha pól rưstu ČR.

\section{Literatura}

[1] Vizina, A., Horáček, S., Hanel, M. Nové možnosti modelu Bilan. Vodohospodárské technicko-ekonomické informace, 2015, 57(4-5), 7-10

[2] Melišová, E.; Vizina, A.; Staponites, L. R.; Hanel, M. The Role of Hydrological Signatures in Calibration of Conceptual Hydrological Model. Water 2020, 12, 3401

\section{Autoři}

Ing. Adam Vizina, Ph.D., ${ }^{1,2}$

凶adam.vizina@vuv.cz

ORCID: 0000-0002-4683-9624

Ing. Irina Georgieová1,2

凶irina.georgieova@vuv.cz

ORCID: 0000-0002-5760-6471

Ing. Eva Juranová

凶eva.juranova@vuv.cz

ORCID: 0000-0001-9021-7307

Ing. Jan Hlom ${ }^{1}$

凶jan.hlom@vuv.cz

ORCID: 0000-0002-1365-3604

${ }^{1}$ Výzkumný ústav vodohospodářský T. G. Masaryka, veřejná výzkumná instituce

2 Česká zemědělská univerzita v Praze, Fakulta životního prostředí

Př́spěvek prošel lektorským řízením.

DOI: 10.46555/VTEI.2021.01.005 


\section{PREDICTION MODEL OF WATER \\ QUALITY AROUND PRAGUE}

\section{VIZINA, A. ${ }^{1,2}$; GEORGIEVOVA, I.1,2; JURANOVA, E. ${ }^{1}$; HLOM, J. ${ }^{1}$}

${ }^{1}$ T. G. Masaryk Water Research Institute, p. r. i.

${ }^{2}$ Czech University of Life Sciences Prague

Keywords: water quality - hydrology - discharges - prediction - Prague

Recently, the impacts of climate change on the water regime in the natural conditions have been much discussed topic - not only among the scientific community. The project was focused on the cultural landscape in the immediate vicinity of the city of Prague, where climatological variables, flows and water quality were monitored at eight pilot sites (river basins), which began in April 2018 and ended in May 2020. The water quality of the Prague streams were evaluated at the Testing Laboratory for Environmental Technology and Components TGM WRI, p. r. i. The long-term runoff regime was simulated by the BILAN model. Selected indicators were evaluated and formed the basis for a simulation model of water quality based on precipitation and runoff characteristics. Concentrations were derived based on regression relationships between the current discharges and the concentration of the selected chemical variable. This created a simulation model, which is available for explorationvia a map application on the project website heis.vuv.cz/projekty/praha-adaptacniopatreni. The results from the monitoring are available within the interactive application or on the project geoportal. 